Meta

Journal des traducteurs

Translators' Journal

\title{
English-to-Spanish Translation and Manuscript Culture in Eighteenth-Century Spain
}

\section{John Stone}

Volume 60, numéro 2, août 2015

$60^{\mathrm{e}}$ anniversaire. Les horizons de la traduction : retour vers le futur $60^{\text {th }}$ Anniversary. Translation's Horizons: Back to the Future

60mo aniversario. Los horizontes de la traducción: regreso al futuro

URI : https://id.erudit.org/iderudit/1032923ar

DOI : https://doi.org/10.7202/1032923ar

Aller au sommaire du numéro

Éditeur(s)

Les Presses de l’Université de Montréal

ISSN

0026-0452 (imprimé)

1492-1421 (numérique)

Découvrir la revue

Citer ce document

Stone, J. (2015). English-to-Spanish Translation and Manuscript Culture in Eighteenth-Century Spain. Meta, 60(2), 372-372.

https://doi.org/10.7202/1032923ar d'utilisation que vous pouvez consulter en ligne. 


\title{
English-to-Spanish Translation and Manuscript Culture in Eighteenth-Century Spain
}

\author{
John STONe \\ Universitat de Barcelona, Barcelona, Spain \\ John.stone@ub.edu
}

In a recent paper on the readership for English-language print matter in eighteenthcentury Spain, I argued that networks underpinned by kinship and local ties can be plotted geographically in ways that are not local, nor indeed restricted to metropolitan centres in the same national territory; that English may have flown under that radar of state and ecclesiastical control of print (corroborated by the extreme poverty of Inquisition reports on English books); and that the culture of cosmopolitans was layered. I argue that multilingualism in less common language pairs - such as Spanish and English - that is, multilingualism that falls outside the ordinary hierarchy of differential literacies, may have constituted a more effective kind of cosmopolitanism because it was seldom programmatically so. In this paper, I want to attempt an extension of these paradigms to translation, as it is during the eighteenth century that translation becomes more self-consciously nationalised. The informal distribution networks of my first study will find counterparts in manuscript, rather than print, translations in the present paper. Just as state efforts to control the circulation of print were foiled by smuggling, bribery, and the use of diplomatic post, the state licencing regime for translation could be sidestepped by restricting a translated text to the older, narrow circuits of manuscript reproduction and distribution; and MS translations from English have met with a different institutional reception (when produced in an institutional setting) precisely because the source language was rare, and the translator's skill more highly valued. Special attention will be paid to MS translations of Swift's Conduct of the Allies (1720s, Arxiu Municipal de Barcelona), Robertson's History of Charles V (circa 1780, Archivo Histórico Nacional, Sección Nobleza), John M’Farlan's Inquiries Concerning the Poor (circa 1790, Biblioteca Nacional de España), and Thomas Browne's Pseudodoxia (circa 1774, Universidad Complutense).

John Stone is the Serra Hunter fellow in English Literature at the Universitat de Barcelona. In recent years his research has focused on English as a language of culture in eighteenth-century Spain, with a particular emphasis on personal and institutional library formation, book smuggling, and instances of direct English-to-Spanish translation. He has enjoyed fellowships at the Beinecke Library (Yale University) and the National Library of Scotland, the latter as a British Society for Eighteenth-Century Studies Visiting Scholar; and a research award at the University of Aberdeen's Sir Duncan Rice Library. He is currently engaged in studies of the eighteenth-century Royal Scots College, Valladolid, and of Thomas David Boswell as an agent of Anglo-Spanish cultural transfer in the circle of the eighteenth-century Scottish banker Robert Herries. He is to edit T. D. Boswell's correspondence for The Yale Edition of the Private Papers of James Boswell. 